\title{
Micro Enterprises in Nepal: Prospect and Practices
}

\author{
Bir Bahadur Karki \\ Lecturer in Management \\ Prithivi Narayan Campus \\ Tribhuvan University, Nepal \\ Email: bbkarki@gmail.com
}

\begin{abstract}
The Government of Nepal (GoN), Ministry of Industry (MoI) is especially responsible for development of micro enterprises (MES). With the support of United Nations Development Programme (UNDP), a new programme has been launching since 1998 i.e. micro enterprise development programme (MEDEP) with the aim of improve the socio economic condition of the low income families and socially excluded people in Nepal. The time between 1999 and 2011, 53345 micro enterprises are created by MEDEP in Nepal. A little more than two third i.e. 67.9 percentage micro enterprises are operated by women entrepreneurs and remaining enterprises i.e. 32.1 percentage enterprises are operated by male entrepreneurs. Out of five development region, central development region has got success to establish more MEs i.e. 15573 in number and 29.2 percentages. In the context of types of caste involved in MEs, higher number of Janajati (35.6\%) are involved, then after Brahaman/Chhetri (35.3\%), Dalit (22.0) and other caste (7.1\%) in total. In different development region, higher numbers of Dalit (35.4\%) and other caste (15.7\%) are conducted MEs in eastern development region. Like it, higher number of Janajati (46.7\%) and Brahaman/Chhetri (57.1\%) are conducted MEs in central development region and far-western development region respectively.
\end{abstract}

Key Words: development, micro enterprise, MEDEP, poverty alleviation, percentage

\section{Introduction}

According to industrial policy 2010, on the basis of investment and nature of industry, industries are classified into five group i.e. micro enterprises, traditional and other cottage industries, small scale industries, medium scale industries and large scale industries (Ministry of Industry (MoI), 2010). In Industrial policy 2010, a defined micro enterprise is:

a) Fixed investment up to NRs 200,000 except land and building.

b) Self managed (managed by entrepreneur her/himself). 
Janapriya Journal of Interdisciplinary Studies, Vol. 2, No.1 (December 2013)

c) Employment up to 9 person including entrepreneur.

d) Amount of annual transaction less than NRs 2,000,000 and

e) Use of power or energy less than $10 \mathrm{KW}$, if used.

Micro enterprise policy 2008 defined as “ Micro enterprise" means any industry, enterprise or other service business, based particularly on agriculture, forest, tourism, mines and handicraft, which meet the following condition: i) In the case of manufacturing industry, enterprise involving the investment of fixed capital of not exceeding two hundred thousand rupees, except house and land, in the case of a service enterprise, an industry, enterprise involving the investment of fixed capital of not exceeding one hundred thousand ruppes. Ii) The entrepreneur himself or herself is involved in the management. iii) A maximum of nine workers including the entrepreneur are employed. iv) It has annual turnover of less than two million rupees. v) If it uses an engine or equipment is less than five kilowatt. Provided that notwithstanding anything contained above, any industry or enterprise which manufacturing liquors, cigarettes or other tobacco products or for the establishment of which approval has to be taken will not be considered as a micro enterprise (MoICS, 2008).

Ministry of Small and Medium Industry, Government of India (GoN), defined micro enterprise (manufacturing sector) as "does not exceed twenty five lakh (Rs 25,00,000) investment on plant and machinery" and micro enterprise (Service sector) defined as "does not exceed ten lakh (Rs. 10,00,000) investment in equipment"( Indian Gazette, 2006).

Government of Nepal (GoN) established micro, cottage and small industry development fund through budget speech of FY 2061/062 (MOI, 2068 B.S.).

According to National population census 2011, total population of Nepal is $264,94,504$ till 22 June, 2011 and annual average population growth rate of about 1.35 percent. Most of the people i.e. 83 percent people are lived in rural area only 17 people are lived in urban area (CBS, 2012). According to report on the Nepal Labor Force Survey (NLFS) 2008, 15 years old or more than it currently employment are involved in agriculture sector by 73.9 percent and in non-agricultural sector by 26.1 percent which were 76 percent and 24 percent in agro-sector and non-agro-sector in last census respectively (CBS, 2008).

Micro-Enterprises Development programme (MEDEP) was initiated in 1998 with the technical and financial support of the United Nations Development Program (UNDP) during the government's ninth five year plan with its main objective of poverty alleviation through developing micro-enterprises and creating off-farm employment opportunities for rural poor and socially excluded (Pun, 2010).

The goal of MEDEP is to improve the socio-economic conditions of the lowincome families and socially excluded people in Nepal. Similarly, the livelihoods and increase the income of low-income families through micro-enterprise development and employment generation. 
The MEDEP is able to created 53,345 micro-entrepreneurs and is able to generated employment opportunities for 54,240 peoples. Out of total entrepreneurs, entrepreneurs are concerned under 68 percent women, 20 percent Dalit and 67 percent young people. Out of total employment generated, 33 percent i.e. 17,883 and 67 percent 36,342 people are concerned with men and women respectively $(\mathrm{CCO}, 2012)$. Now, the program operates in 38 districts and has helped create 56,698 micro entrepreneurs, 68 percent being women (Australian Embassy, 2013).

Local firms should be made strengthen with appropriate government policies like public private partnership (PPP), one village one product (OVOP) and regulation and through implementation of such policies and programme, they can able to achieve the goal of poverty alleviation and to solve unemployment problems (Karki, 2011).

Some Organization and Their Activities which works in the Field of Entrepreneurship Development Sector in Nepal

Industrial Enterprise Development Institute (IEDI):-The Industrial Enterprise Development Institute (IEDI), a national level organization committed to entrepreneurship development has been working in the field of entrepreneurship development since 1996. IEDI is a successor organization of former Small Business Promotion Project (SBPP), which was a joint project of GTZ and GoN (Thapa and Karki, 2012).

Micro Enterprise Development Programme (MEDEP):-MEDEP was started in 1998 covering only 10 districts and has reached to 38 districts up to 2012 and has already completed three project phases. Main theme of MEDEP is "Poverty reduction through micro enterprise development" (Pun, 2012).

Rural Enterprises Assistance Program (REAP):- REAP was launched from October 2002 to 2008 in seven hilly and mountains district of Nepal. The working districts were Taplejung, Panchthar, Illam, Humla, Jumla, Mugu and Dolpa. REAP aimed at developing local capacity with a view to increase access of rural entrepreneurs to business development services. REAP mainly focused on enterprise creation and development, capacity building of partners and subsector development of cardamom, hand tea and seabuckthrone (Thapa, 2012).

Elam plus Model (Helvetas Nepal):- Elam plus is an informal sector enterprise development generation program of HELVETAS. The main clients of Elam are: i) Socially and economically disadvantaged; ii) Earning less than NRs. 3000/months; and households member; iii) Food sufficiency less than 6 months; land less or land poor less than 8 Kattha ; iv) Micro entrepreneurs, entrepreneurial attitude; enterprise service providers from private sector. Up to now, 12,165 clients in off farm based enterprise have been benefited (Poudel, 2012).

Business Incubation Model:- It was introduced in 2006 by GoN. It is a platform to transform innovative ideas into dynamic enterprise for national and global competitiveness. It monitors the activities of management consultant and acts as a supervisory body (Karel, 2012). 
One Village One Product (OVOP):- The OVOP concept was introduced in 2006 in a public private partnership based approach. The program implemented to achieve the following objectives: - qualitative and commercial production of local product, value addition, branding, internal and external market promotion, employment generation and socio-economic development of rural community. OVOP is selected on the basis of local comparative advantages, local skills and local leadership to own the products (Shakya, 2012).

\section{Review of Literature}

The Nepalese economic scenario reveals a predominance of the primary sector, slow growth and mass deprivation. With virtually no modern physical infrastructure in a highly congested and difficult terrain, limited exploitable natural resources, small number skilled labour forces, the option for rapid development have been limited and the choices uncertain and limit. The industrial sector is not developed and is only in the form of smaller scale industries (Bajracharya, 2007). It has been witnessed that micro enterprises have become increasingly popular in the new development agenda across the globe and more so in the developing world to address income and employment opportunities. As through the development of micro-enterprise the people in rural areas get income and employment (UNDP, 1998). Bajracharya (2003) had observed that the prevailing policy of the government is not very encouraging to the MSE Sector. The laws and regulations generally cover only industrial enterprises and do not cover enterprises in other sector. MEDEP was launched since 1998 with in 10 districts and now the programme is expanded into 36 districts at the end of 2010 . Out of 36 districts, 18 districts are from hills, 12 districts from terai and 6 districts from mountain territory of Nepal. These 36 districts also covered five development regions. The rapid industrial development of a country mainly depends upon the role and abilities of entrepreneurs. The role of entrepreneurs is directly affected by the personal qualities of the entrepreneurs, their socio-economic background, business environment and government support etc. So far as the development of entrepreneurship in India is concerned, it is growing very fast but even today it has failed in promoting entrepreneurship in rural sector (Jha, 2010).

Main objective of the study is to explore numbers of micro enterprises operated/created in five development region of Nepal. Other objectives of the study are as follows:-

i) To analyze number of micro-enterprises operated by women and men.

ii) To compare of MEs in different development region on the basis of caste.

\section{Data and Methods}

The research is based on descriptive cum analytical research approach. The data are collected from secondary sources. Secondary data are collected, specially, through annual report of micro enterprise development programme (MEDEP) published by MEDEP. Collected data are edited and tabulated as per required of research. For analysis of data some statistical tools are used. Percentage is used for data analysis. 


\section{Result and Discussion}

The scenario of number of micro enterprises in Nepal in different five development regions with gender and caste/tribes are presented in table number 1 and 2 respectively.

Department of Cottage and Small Industry (DCSI) under Ministry of Industry (MOI) also started and launched micro-enterprise development programme in 10 districts from F.Y. 2067/68 with the aim of poverty alleviation through micro-enterprise development. In these years, the department is able to create 1313 entrepreneurs (MOI, 2069). MEDEP has been also launched in 36 district \& five development region of Nepal and is able to create more than 53,345 entrepreneurs. The table 1 shows that numbers of entrepreneurs are created in different development region with numbers of genders and their ratio in percentages.

Table 1: Number of Micro Entrepreneurs on the basis of Gender

(Between Time period of 1999 to 2011)

\begin{tabular}{|l|l|l|l|l|l|l|}
\hline $\begin{array}{l}\text { Gender } \rightarrow \\
\text { Development } \\
\text { Region } \downarrow\end{array}$ & Male & Percentage & Women & Percentage & Total & $\begin{array}{l}\text { Percentage } \\
\text { of micro } \\
\text { enterprises }\end{array}$ \\
\hline Eastern & 3348 & 36.3 & 5877 & 63.7 & 9225 & 17.3 \\
\hline Central & 4436 & 28.5 & 11137 & 71.5 & 15573 & 29.2 \\
\hline Western & 2315 & 29 & 5675 & 71.0 & 7990 & 15.0 \\
\hline Mid-western & 4025 & 30.9 & 9013 & 69.1 & 13038 & 24.4 \\
\hline Far-western & 3013 & 40.1 & 4506 & 59.9 & 7519 & 14.1 \\
\hline Total & 17137 & 32.1 & 36208 & 67.9 & 53345 & 100.0 \\
\hline
\end{tabular}

Sources: Micro Enterprise Development Programme, 2012

Between time periods of 1999 to 2011, total number of micro enterprises established of about 53345. The highest number of micro enterprises is established in central development region, whereas, the lowest number of micro enterprises are established in far-western development region. The numbers of micro enterprises are in these regions 15573 and 7519 and in percentage 29.9 and 14.1 respectively. Mid-western development region, eastern development region and western development region have occupied second, third and fourth ranked in the terms of number of micro enterprises. In these regions, total numbers of micro enterprises are 13038, 9225, and 7990 respectively. In the case of owner of micro enterprises, more than two third i.e. 67.9 percentage enterprises are operated by women entrepreneurs and remaining enterprises i.e. 32.1 percentage enterprises are operated by male entrepreneurs.

The Scenario of Micro Enterprises in different development region with major caste/ tribes of Nepal is presented in table 2. 
Janapriya Journal of Interdisciplinary Studies, Vol. 2, No.1 (December 2013)

Table 2: Number of Micro Enterprises Developed by MEDEP

\begin{tabular}{|l|l|l|l|l|l|l|l|l|l|l|}
\hline $\begin{array}{l}\text { Caste / } \\
\text { Development } \\
\text { Region }\end{array}$ & Dalit & $\%$ & Janajati & $\%$ & $\begin{array}{l}\text { Brahaman/ } \\
\text { Chhetri }\end{array}$ & $\%$ & Others & $\%$ & Total & $\%$ \\
\hline Eastern & 3266 & 35.4 & 3114 & 33.8 & 1394 & 15.1 & 1451 & 15.7 & 9255 & 17.3 \\
\hline Central & 2605 & 16.7 & 7280 & 46.7 & 3864 & 24.8 & 1824 & 11.7 & 15573 & 29.2 \\
\hline Western & 2111 & 26.4 & 3100 & 38.8 & 2468 & 30.9 & 311 & 3.9 & 7990 & 15.0 \\
\hline Mid-western & 2259 & 17.3 & 3769 & 28.9 & 6839 & 52.5 & 171 & 1.3 & 13038 & 24.4 \\
\hline Far-western & 1506 & 20.0 & 1710 & 22.7 & 4290 & 57.1 & 13 & 0.2 & 7519 & 14.1 \\
\hline Total & 11747 & 22.0 & 18973 & 35.6 & 18855 & 35.3 & 3770 & 7.1 & 53345 & 100 \\
\hline
\end{tabular}

Sources: MEDEP, 2012 (Data based from 1999 to 2011)

As discuss in table no. 1, total number of micro enterprises in Nepal are 53345, which are created by micro enterprises development programme. The table no. 2 is presented number of micro enterprises which are created and operated by different tribes and caste in Nepal. In eastern development region, Dalits have been operated more micro enterprises i.e. $3266(35.4 \%)$ and Janajati created $3114(33.8 \%)$; others caste created 1451 (15.7\%) and Brahaman/Chhetri (BC) created 1394 (15.1\%). It seemed that Dalit, Janajati, others caste and Brahaman/Chhetri caste created and operated highest number to lowest number of micro enterprise respectively. In central development region, out of total number of micro enterprises 15573 Janajati caste are able to create highest number of micro enterprise i.e. 7280 (46.7 \%) then after Brahaman/Chhetri occupied by $24.8 \%$, Dalit by $16.7 \%$ and others caste by $11.7 \%$ of micro enterprises. In western development region, out of total number of micro enterprises i.e.7990 Janajati occupied highest number i.e. 3100 (38.8 \%), then after Brahaman/Chhetri, Dalit, and others caste higher number to lower number of micro enterprises respectively. Brahaman/Chhetri (BC) castes dominated to others castes in mid-western and far-western development region in the case of number of micro enterprises created and operated by various castes. In these regions, Brahaman/Chhetri castes occupied 57.1 percentages and 52.5 percentages in mid-development region and far-development region respectively. Jha (2010) conducted a study on "problems and prospects of rural entrepreneurship in Bihar- a case study" and find out that entrepreneurship activity was very high in the general category of Hindus and Muslims both but it was almost marginal in case of SC category. Out of total respondents 800,520 i.e. 65 percent people are belongs to general caste and 264 i.e. 33 percent people are concerned with $\mathrm{BC}$ and only 16 i.e. 2 percent people concerned with SC in the case of caste and religion wise profile of entrepreneurs in Bihar (India) (Jha, 2010).

\section{Conclusion}

For economy development of the nation, micro and small enterprise are more appropriate enterprise rather than medium and large scale enterprise in developing contries like in Nepal. Besides ministry of industry, other organization and programme 
like IEDI, MEDEP, and OVOP are also working for the development of MEs. The time between 1999 and 2011, 53,345 micro enterprises are created by MEDEP in Nepal. In the case of owner of micro enterprises, more than two third i.e. 67.9 percentage micro enterprises are operated by women entrepreneurs and remaining enterprises i.e. 32.1 percentage enterprises are operated by male entrepreneurs. Out of five development regions, central development has got success to establish more micro enterprises $(15,573)$ and more women $(71.5 \%)$ are involved in such enterprises rather than other region. In the context of Far-western development region, more men entrepreneurs $(40.1 \%)$ are involved in micro enterprises comparing with other regions and less number of micro enterprises is established. In the context of types of caste involved in MEs, higher number of Janajati are involved (53.6\%), then after Brahaman/Chhetri $(53.3 \%)$, Dalit $(22.0 \%)$ and other caste $(7.1 \%)$ respectively. In different development region, higher numbers of Dalit (35.4\%) and other caste (15.7\%) are conducted MEs in eastern development region. Like it, higher number of Janajati (46.7\%) and Brahaman/ Chhetri $(57.1 \%)$ are conducted MEs in central development region and far-western development region respectively.

\section{Acknowledgement}

I wish to eaxtend my sincere thanks to Janapriya Research and consultancy centre (JRCC), Janapriya Multiple Campus (JMC), Pokhara for providing such kind of academic career development opportunity. I would like to thanks professor Vikash Kumar KC, Ph.D., TU, for his continuous support in reviewing and suggestion of this paper.

\section{References}

Australian Embassy. (7 March, 2013). Australian embassy celebrate international women's day 2013. Kathmandu: Australian Embassy

Bajracharya, Puskar et al. (2003). Integrated report on MSE-PR, submitted to ILO, Kathmandu: Nepal

Bajracharya, Puskar. (2007). Regional development strategy. Kathmandu: ADBNPC

Bajracharya, Puskar et al. (2003), Micro and small enterprises policy in Nepal, Review of Legal and Policy Framework. Kathmandu: ILO/UNDP

Canadian Cooperation Office (CCO)-Nepal. (2012). A target evaluation of micro enterprise development programme. Kathmandu: CCO- Nepal

Government of India. (2006). The gazette of India (extraordinary) part II, section 3, sub-section (ii) No. 1152 (Saturday, September 30). New Delhi: By Authority

Jha, Nagendra Kumar. (2010). Problems and prospects of rural entrepreneurship in Bihar: A case study, Patna University Journal vol. 34, annual pp 178-186

Karki, Bir Bahadur. (2011). Doing business and role of Government for entrepreneurship development, The journal of Nepalese Business Studies, Vol. VII No. 1 Dec. 2010/2011.

Kharel, Krishna. (2012). A paper presented on business incubation model on 27 June, 2012, a report on a workshop on micro and small enterprise best practice in Nepal. Kathmandu: IEDI 
Ministry of Industry. (MoI). (2010). Industrial policy-2010.Kathmandu: MoI

Ministry of Industry. (MoI). (2008). Micro Enterprise Policy-2008. Kathmandu.MoI

Ministry of Industry. (2068). Fund operating procedure of micro, cottage, and small industry development fund-2068( B.S). Kathmandu: MOI.

Ministry of Indsutry. Commerce and Supplies (MoICS). (2008). Micro enterprise policy 2008. Kathmandu: MoICS

National Planning Commission (NPC) Central Bureau of Statistics (CBS). (2012). National population and housing census 2011 (National Report), Vol. 01, NPHC 2011. Kathmandu: NPC, CBS

Poudel, Sandeep. (2012). A paper presented on Elam plus model (Helvetas Nepal) on 27 June, 2012, a report on a workshop on micro and small enterprise best practice in Nepal. Kathmandu: IEDI

Pun, Lakshman. (2010). Introduction to Micro Enterprise Development Model and Its Achievement in Nepal, Micro-Enterprise Development for Poverty Alleviation. Vol 1 (MEDEP/ UNDP, Ministry of Industry (MOI).

Pun, Lakshman. (2012). A paper presented on micro enterprise development model (MEDEP model) on 27 June, 2012, a report on a workshop on micro and small enterprise best practice in Nepa. Kathmandu: IEDI

Shakya, Ganesh. (2012). A paper presented on one village one product (ovop model) on 27 June, 2012, a report on a workshop on micro and small enterprise best practice in Nepal, Kathmandu: IEDI

United Nationals Development Programme (UNDP). (1998).Overcoming human poverty. New York: UNDP Poverty Report.

Thapa, Dilip and Karki, Bishwa. (2012). A paper presented on rural enterprise development programme (REAP model) on 27 June, 2012, a report on a workshop on micro and small enterprise best practice in Nepal. Kathmandu: IEDI 